\title{
Editorial: The biodiversity of trematodes of fishes
}

\author{
Thomas H. Cribb
}

Received: 5 January 2016/ Accepted: 6 January 2016

(C) Springer Science+Business Media Dordrecht 2016

"Biodiversity" is a term capable of almost limitless interpretation. For the particular context of trematodes of fishes, an understanding of biodiversity might be taken to mean that we

- Know what species exist

- Know how they are related

- Know the range of their hosts

- Know their geographical distribution

- Know their life-cycles

Here, progress in these areas is considered in seven papers that arose from a workshop (The Biodiversity of Trematodes of Fishes) held as part of the 9th International Symposium on Fish Parasites in Valencia in September 2015.

Five papers review progress in the description of trematodes of fishes focusing on the faunas of the Mediterranean Sea, the Atlantic and eastern Pacific, and the Indo-west Pacific, and freshwater fishes of the Old and New Worlds. Together these papers show that there are thousands of species known but that there remain an unpredictable number of undescribed

Special Issue on Biodiversity of Trematodes of Fishes, Guest Edited by Thomas H. Cribb.

T. H. Cribb $(\square)$

School of Biological Sciences, The University of

Queensland, St Lucia, QLD 4072, Australia

e-mail: t.cribb@uq.edu.au species, and many that require improved characterisation. An unsurprising outcome of these analyses is that the components of the global fauna have different levels of understanding. The faunas of Europe and North and Middle America are probably the best known, but for no area is there any suggestion that understanding approaches completion. None of the analyses predict total richness for their respective regions; this suggests that the faunas are too poorly known for a prediction to be convincing.

Several authors here comment on the small and diminishing pool of taxonomists available to study the taxonomy of trematodes. The issue is controversial globally. Some (e.g. Costello et al., 2013a, b) argue that "taxonomic effort has never been greater" and that taxonomy is thriving, whereas others disagree vehemently (Mora et al., 2013; Bebber et al., 2014; De Carvalho et al., 2014). Examination of the chart of authors describing most species of trematodes during the last 16 years generated by the World Register of Marine Species (WoRMS, 2015) is instructive. The 30 most productive workers described between 17 and 354 species over this period. Only three authors described more than 100 species whereas 25 described 17-48. Several are now retired (though some are still active) (e.g. Bray, Gibson, Machida) and two are deceased (Manter \& Yamaguti). Several others are closer to the end of their careers than to the start (Blend, Cribb, Dronen, Justine, Kostadinova, and Madhavi). Several younger taxonomists have made 
significant contributions (e.g. Bott, Bullard, Cutmore, Hall, Hunter, Miller, Nolan and Pulis) but some have already left the field and may make no further contribution. Although the data relate only to marine taxa and for trematodes of host groups in addition to fishes, the implications can be considered relevant both for (more narrowly) just trematodes of fishes and (more broadly) for all trematodes. Certainly the pool of scientists making a sustained contribution to this field is small relative to the size of the task.

An important aspect of the analyses of trematode richness is the size of the task of cataloguing the fauna. In this context the opportunity offered by the World Register of Marine Species is one that must be grasped by the trematode community. The possibilities of the system were presented at the Workshop by Professor Geoff Boxshall of the Natural History Museum, London. Already the database is a tremendous resource for trematodes, largely through the efforts of Dr David Gibson, also of the Natural History Museum, London. However, there is great potential to incorporate nonmarine taxa as well as host, distributional and lifecycle data. It is clear that "many hands make light work" - the trematode community cannot expect the likes of David Gibson to do all the work forever.

An attraction of the Trematoda as a group for study is the complexity and variety of life-cycles. Elucidating life-cycles is critical to complete understanding of trematodes, but it is a formidable task. One paper in this issue considers knowledge of life-cycles of trematodes incorporating freshwater molluscs in Europe. There seems little doubt that this region is as well-known as any, and yet only about half the trematodes of fishes have been linked to their molluscan hosts. For marine species, probably no more than a tenth have been linked anywhere and often the proportion is worse than that. Specifically for trematodes of fishes it is noteworthy that life-cycles have been demonstrated relatively recently for two hitherto completely unknown families - Gyliauchenidae Fukui, 1929 (see Al-Jahdali \& Hassanine, 2012) and Gorgocephalidae Manter, 1966 (see O'Dwyer et al., 2015). However, the vast majority of trematode life-cycles remain unknown.

The papers in this issue comment repeatedly on the need for, and potential of, molecular approaches in the recognition of species, the linking of life-cycle stages, and the inference of phylogenetic relationships. The linking of life-cycle stages and the recognition of species relates on the one hand to the problems of phenotypic variation which may obscure shared identity and, on the other, to the problem of cryptic species. Cryptic trematode species are now encountered so commonly that they can almost be expected and should certainly be suspected (Pérez-Ponce de León \& Nadler, 2010). Clearly, molecular approaches are critical to the recognition of cryptic species, as has now been shown for numerous trematode families (e.g. Miller \& Cribb, 2007; Carreras-Aubets et al., 2011; Rosas-Valdez et al., 2011; Curran et al., 2013). The potential of molecular approaches for the elucidation of life-cycles has meant that they are fast dominating the field (e.g. Heneberg et al., 2015; Kudlai et al., 2015; Muñoz et al., 2015; Shirakashi et al., 2016). In view of this importance, one paper here outlines 'best practice' for the molecular characterisation of trematodes in detail.

The development of understanding of phylogenetic relationships of trematodes is now seemingly dependent on molecular data; morphological characters seem too sparse and too unreliable to allow reliable progress. It is striking that, in almost every instance in which groups of trematodes are subjected to molecular phylogenetic analysis, unexpected but plausible changes in our understanding of relationships emerge (e.g. Choudhury et al., 2007; Bray et al., 2009; Cutmore et al., 2013; Pulis et al., 2014; Pinto et al., 2015). Despite this, the field can be considered to be in its infancy with the vast majority of genera and species not yet subjected to molecular phylogenetic analysis.

Huber (2014) observed that for pholcid spiders "a complete (or near-complete) inventory is neither realistic nor necessary and that knowing the majority of species of a particular group will answer most questions on that taxon's biology". This observation rings true for the trematodes of fishes; at the present rate of study we cannot aspire to complete knowledge of the fauna. Two trematode-specific observations follow. First, we are by no means close to a point where further study has little value. Secondly, we should target our research into the areas that will improve our understanding most.

\section{References}

Al-Jahdali, M. O., \& Hassanine, R. (2012). The life cycle of Gyliauchen volubilis Nagaty, 1956 (Digenea: Gyliauchenidae) from the Red Sea. Journal of Helminthology, $86,165-172$. 
Bebber, D. P., Polaszek, A., Wood, J. R. I., Barker, C., \& Scotland, R. W. (2014). Taxonomic capacity and author inflation. New Phytologist, 202, 741-742.

Bray, R. A., Waeschenbach, A., Cribb, T. H., Weedall, G. D., Dyal, P., \& Littlewood, D. T. J. (2009). The phylogeny of the Lepocreadioidea (Platyhelminthes, Digenea) inferred from nuclear and mitochondrial genes: Implications for their systematics and evolution. Acta Parasitologica, 54, 310-329.

Carreras-Aubets, M., Repullés-Albelda, A., Kostadinova, A., \& Carrassón, M. (2011). A new cryptic species of Aponurus Looss, 1907 (Digenea: Lecithasteridae) from Mediterranean goatfish (Teleostei: Mullidae). Systematic Parasitology, 79, 145-159.

Choudhury, A., Valdez, R. R., Johnson, R. C., Hoffmann, B., \& Pérez-Ponce de León, G. P. P. (2007). The phylogenetic position of Allocreadiidae (Trematoda : Digenea) from partial sequences of the $18 \mathrm{~S}$ and $28 \mathrm{~S}$ ribosomal RNA genes. Journal of Parasitology, 93, 192-196.

Costello, M. J., May, R. M., \& Stork, N. E. (2013a). Can we name earth's species before they go extinct? Science, 339, 413-416.

Costello, M. J., Wilson, S., \& Houlding, B. (2013b). More taxonomists describing significantly fewer species per unit effort may indicate that most species have been discovered. Systematic Biology, 62, 616-624.

Curran, S. S., Tkach, V. V., \& Overstreet, R. M. (2013). Molecular evidence for two cryptic species of Homalometron (Digenea: Apocreadiidae) in freshwater fishes of the southeastern United States. Comparative Parasitology, 80, 186-195.

Cutmore, S. C., Miller, T. L., Curran, S. S., Bennett, M. B., \& Cribb, T. H. (2013). Phylogenetic relationships of the Gorgoderidae (Platyhelminthes: Trematoda), including the proposal of a new subfamily (Degeneriinae n. subfam.). Parasitology Research, 112, 3063-3074.

De Carvalho, M. R., Ebach, M. C., Williams, D. M., Nihei, S. S., Rodrigues, M. T., et al. (2014). Does counting species count as taxonomy? On misrepresenting systematics, yet again. Cladistics, 30, 322-329.

Heneberg, P., Faltýnková, A., Bizos, J., Mala, M., Ziak, J., \& Literak, I. (2015). Intermediate hosts of the trematode Collyriclum faba (Plagiochiida: Collyriclidae) identified by an integrated morphological and genetic approach. Parasites \& Vectors, 8, 085.

Huber, B. A. (2014). Progress and prospects in taxonomy: what is our goal and are we ever going to reach it? Journal of Arachnology, 42, 142-147.

Kudlai, O., Cutmore, S. C., \& Cribb, T. H. (2015). Morphological and molecular data for three species of the
Microphallidae (Trematoda: Digenea) in Australia, including the first descriptions of the cercariae of Maritrema brevisacciferum Shimazu et Pearson, 1991 and Microphallus minutus Johnston, 1948. Folia Parasitologica, 62, 053.

Miller, T. L., \& Cribb, T. H. (2007). Two new cryptogonimid genera (Digenea, Cryptogonimidae) from Lutjanus bohar (Perciformes, Lutjanidae): analyses of ribosomal DNA reveals wide geographic distribution and presence of cryptic species. Acta Parasitologica, 52, 104-113.

Mora, C., Rollo, A., \& Tittensor, D. P. (2013). Comment on "Can We Name Earth's Species Before They Go Extinct?". Science, 341.

Muñoz, G., Valdivia, I., \& López, Z. (2015). The life cycle of Prosorhynchoides carvajali (Trematoda: Bucephalidae) involving species of bivalve and fish hosts in the intertidal zone of central Chile. Journal of Helminthology, 89, 584-592.

O’Dwyer, K., Faltýnková, A., Georgieva, S., \& Kostadinova, A. (2015). An integrative taxonomic investigation of the diversity of digenean parasites infecting the intertidal snail Austrolittorina unifasciata Gray, 1826 (Gastropoda: Littorinidae) in Australia. Parasitology Research, 114, 2381-2397.

Pérez-Ponce de León, G., \& Nadler, S. A. (2010). What we don’t recognize can hurt us: a plea for awareness about cryptic species. Journal of Parasitology, 96, 453-464.

Pinto, H. A., de Melo, A. L., \& Brant, S. V. (2015). Where are the South American freshwater turtle blood flukes (Trematoda: Spirorchiidae)? The first morphological and molecular analysis of spirorchiid cercariae from freshwater snails in Brazil. Parasitology International, 64, 553-558.

Pulis, E. E., Curran, S. S., Andres, M. J., \& Overstreet, R. M. (2014). Change in rank of Megaperidae (Trematoda) to Megaperinae within the Apocreadiidae and description of Haintestinum amplum n. g., n. sp. Parasitology International, 63, 269-274.

Rosas-Valdez, R., Choudhury, A., \& Pérez-Ponce de León, G. (2011). Molecular prospecting for cryptic species in Phyllodistomum lacustri (Platyhelminthes, Gorgoderidae). Zoologica Scripta, 40, 296-305.

Shirakashi, S., Tani, K., Ishimaru, K., Shin, S. P., Honryo, T., Uchida, H., \& Ogawa, K. (2016). Discovery of intermediate hosts for two species of blood flukes Cardicola orientalis and Cardicola forsteri (Trematoda: Aporocotylidae) infecting Pacific Bluefin tuna in Japan. Parasitology International, 65, 128-136.

WoRMS Editorial Board (2015). World Register of Marine Species. Available from http://www.marinespecies.org at VLIZ. Accessed 2016-1-5. 